\title{
THE STUDY OF ETHANOLIC EXTRACT OF BINAHONG LEAVES (ANREDERA CORDIFOLIA [TEN.] STEENIS) AND MULBERRY LEAVES (MORUS NIGRA L.) IN COMBINATION ON HYPERLIPIDEMIC-INDUCED RATS
}

\author{
ELIN YULINAH SUKANDAR*, DEWI SAFITRI, NISRINA NUR AINI
}

Department of Pharmacology and Clinical Pharmacy, School of Pharmacy, Institute Teknologi Bandung, Bandung, Indonesia. Email: elin@fa.itb.ac.id

Received: 30 July 2016, Revised and Accepted: 11 August 2016

\section{ABSTRACT}

Objective: This study aimed to determine the antihyperlipidemic activity of binahong leaves and murbey leaves extracts in combination.

Methods: A total of 28 rats were divided into seven groups: normal, control, simvastatin $3.6 \mathrm{mg} / \mathrm{kg} \mathrm{bw}$, binahong leaves extract $100 \mathrm{mg} / \mathrm{kg}$ bw (B100), mulberry leaves extract $200 \mathrm{mg} / \mathrm{kg}$ bw (M200), combination of binahong extract $50 \mathrm{mg} / \mathrm{kg}$ and mulberry $100 \mathrm{mg} / \mathrm{kg}$ (B50+M100), and combination of binahong extract $100 \mathrm{mg} / \mathrm{kg}$ bw and mulberry $200 \mathrm{mg} / \mathrm{kg}$ bw (B100+M200). Hyperlipidemia was induced by giving rats a high-fat diet along with cholesterol $(200 \mathrm{mg} / \mathrm{kg})$, cholic acid $(0.2 \%$ of chow), and propylthiouracil $(10 \mathrm{mg} / \mathrm{kg} \mathrm{bw})$ for 30 days orally. Then, for the next 14 days, all groups except the control were given the tested substances. Measurement of lipid profile was performed immediately after induction (T0), 7 and 14 days after treatment (T7 and T14, respectively).

Results: There were significant differences on a group of M200, B50+M100, and B100+M200 compared to the control group at T14, with the value $33.68 \%, 34.39 \%$, and $44.81 \%$ (in reduction of total cholesterol [TC]) and 36.86\%, 37.16\%, and 49.99\%, respectively (in reduction of triglyceride [TG]).

Conclusion: Group of M200, B50+M100, and B100+M200 reduced TC and TG level remarkably at day 14. The combination of both extract (B100+M200) considerably shows better activity than either binahong extract or mulberry extract.

Keywords: Binahong, Murbey, Anredera cordifolia, Morus nigra, Antihyperlipidemia.

(C) 2016 The Authors. Published by Innovare Academic Sciences Pvt Ltd. This is an open access article under the CC BY license (http://creativecommons. org/licenses/by/4. 0/) DOI: http://dx.doi.org/10.22159/ajpcr.2016.v9i6.14412

\section{INTRODUCTION}

Dyslipidemia is a metabolic syndrome which is characterized by elevations of one or more lipid profiles including total cholesterol (TC), low-density lipoprotein (LDL), and triglyceride (TG) exceeding the normal range [1]. TC level is considerably in the normal range if the measure is below $200 \mathrm{mg} / \mathrm{dl}$ [2]. In 2013, there were approximately 48\% people over 20 years old suffer from hyperlipidemia and have TC $>200 \mathrm{mg} / \mathrm{dL}$ [3] Meanwhile in Indonesia, according to a survey conducted by Riset Kesehatan Dasar (Basic Health Research) in 2013, there was around 35.9\% of Indonesian people over than 15 years old suffers from hyperlipidemia.

Poor lifestyle contributes to the pathogenesis of dyslipidemia such as high-fat diet without proper physical activities, sedentary lifestyle, and consuming fast food; in addition, genetic also plays a role in dyslipidemia. Dyslipidemia is considered as the major health risk attributing to cardiovascular diseases, such as atherosclerosis, stroke, and coronary heart diseases which may lead to fatality if it is mismanaged $[4,5]$. Such complications come as the highest mortality in the world. There was approximately 17.5 million death case due to cardiovascular diseases in 2012 , which represented about $31 \%$ of global proportion. Thus, earlier prevention is very important to reduce the mortality rate caused by these metabolic disorders.

A lot of traditional herbs are utilized to treat particular disorders, especially in Indonesia. Indonesia is widely known of its Jamu and other traditional medicine together with China and India. Empirically, there are several plants that are being used by Indonesian in treating hyperlipidemia. Research performed by Lestari [6] and Rahman [7] showed that either binahong leaves extract or mulberry leaves extract was able to reduce lipid profile. However, there is a scientific publication that evaluates the pharmacological effect of both extracts in combination. Thus, in this study, we have examined the effect of binahong leaves and mulberry leaves extract in combination in a rat hyperlipidemia model.

\section{MATERIALS AND METHODS}

\section{Materials}

Binahong leaves and mulberry leaves were purchased from Manoko, Lembang, Indonesia. The herbs were then determined in the Herbarium Bandungense, ITB, Indonesia. All materials and chemical reagents used in this study were pharmaceutical grade compounds.

\section{Animals}

A total of 28 free pathogen male Wistar rats were provided by D'Wistar Ciwidey, Bandung. Before the experiment was conducted, rats were acclimatized for 7 days and kept under the standard condition for animal welfare. All procedure in this study has been accepted by the Ethical Commission of Institute Teknologi Bandung.

\section{Extract preparation and quality control determination}

Each herb was air-dried and pulverized before being extracted Powdered crude herb of binahong and mulberry leaves were then extracted by ethanol $70 \%$ and ethanol $95 \%$, respectively, using reflux method for approximately $3 \mathrm{hrs}$. The procedure was repeated 3 times. Subsequently, each extract was filtered and concentrated using rotary evaporator until viscous extract was obtained. Both extracts were kept at refrigerator $4^{\circ} \mathrm{C}$ until analyzing time. Both crude herbs and extracts were standardized with regards to quality control published by the WHO [8], which include determination of secondary metabolites: Alkaloid, flavonoid, saponin, tannin, and steroid/triterpenoid.

\section{Experimental design}

Before experiment, all rats were divided randomly into 7 groups $(n=4)$ including normal group, control group, simvastatin $3.6 \mathrm{mg} / \mathrm{kg}$ bw 
treated group, a group receiving binahong $100 \mathrm{mg} / \mathrm{kg}$ bw (B100), a group treated by mulberry $200 \mathrm{mg} / \mathrm{kg}$ bw (M200), a group receiving binahong $50 \mathrm{mg} / \mathrm{kg}$ bw in combination with mulberry $100 \mathrm{mg} / \mathrm{kg}$ bw (B50+M100), and a group treated by combination of binahong $100 \mathrm{mg} / \mathrm{kg}$ bw and mulberry $200 \mathrm{mg} / \mathrm{kg}$ bw (B100+M200).

Starting from the first week, all groups except the normal group were induced by high-fat diet for 30 days, and long with it, each rat received pure cholesterol $200 \mathrm{mg} / \mathrm{kg}$ bw, cholic acid $0.2 \%$ (of total chow), and propylthiouracil $10 \mathrm{mg} / \mathrm{kg}$ bw orally. After being induced for 30 days, the tested substances were delivered according to each group for approximately 14 days

\section{Lipid profile measurement}

Upon induction, all lipid parameters including TC, TG, and LDL were measured (T0), at day 7 (T7) and 14 (T14) after induction, respectively. These parameters were estimated using an enzymatic colorimetric assay. However, LDL was calculated using Friedewald formula. Blood from tail vein was withdrawn in selected time (T0, T7, and T14) and then collected for approximately $300 \mu \mathrm{L}$. Afterward, the whole blood was centrifugated at $10,000 \mathrm{rpm}$ for 10 minutes to obtain serum. In accordance to the protocol, obtained serum was prepared, mixed with the reagent, and analyzed using a UV-visible (UV-vis) spectrophotometry at $\lambda 546 \mathrm{~nm}$.

$$
\mathrm{LDL}_{\mathrm{c}}(\mathrm{mg} / \mathrm{dl})=\text { Total Cholesterol }-\mathrm{HDL}_{\mathrm{c}}-\frac{\mathrm{TG}}{5}
$$

In cholesterol total measurement, there is a cascade of chemical reaction resulting in a colored compound quinoneimine, which will be measured by UV-vis spectrophotometry. The similar reaction was performed in TG determination, at which resulting in a quinoneimine compound. Meanwhile, the serum level of high-density lipoprotein (HDL) was determined using precipitant dextran sulfate and magnesium sulfate that cause very LDL and LDL to precipitate.

\section{Organ index}

At end point, all rats were sacrificed humanely by placing them at particular chamber where $\mathrm{CO}_{2}$ gas is freely flowed into the chamber. After dead confirmation, liver of each rat was isolated and rinsed in cold saline water before weight measurement. Liver index was calculated by utilizing the following formula:

Liver index $=\frac{\text { A liver weight }(\mathrm{g})}{\text { Rat's body weight }(\mathrm{g})} \times 100 \%$

\section{Histopathological studies}

A freshly isolated liver was soaked in formalin phosphate buffer solution for approximately a week. A piece of the liver which had been embedded in a cassette was washed in alcohol gradually, and following that was immersed in xylol. The liver in embedded cassette was then soaked in liquid paraffin and allowed to become solid before entering slicing procedure. Solidified organ was sliced using microtome that resulting in a slice with a thickness of 3-5 $\mu \mathrm{m}$. It was placed on the object glass and stored in the oven of $55^{\circ} \mathrm{C}$ for a day. Afterward, the slices were stained by hematoxylin-eosin before observing under microscope. Figure of liver tissue was taken carefully utilizing digital devices Optilab.

\section{Statistical Analysis}

All data in this study were expressed as mean \pm standard deviation. The differences were analyzed by independent sample t-test method in SPSS 16.0 Trial version. Differences were considered significant if $\mathrm{p}<0.05$.

\section{RESULTS}

\section{Quality control: Crude herbs and extracts (Table 1)}

The results of quality control of both crude drugs is represented in the Table 1.

\section{TC serum level}

According to references, a normal range of TC was below $200 \mathrm{mg} /$ $\mathrm{dL}$ [2]. Upon 7 day induction, there was a statistically significant increase in groups receiving high-fat diet compared to the normal fed group $(\mathrm{p}<0.05)$. The average values of total serum level were $332.04 \pm 89.28$ and $52.33 \pm 10.44 \mathrm{mg} / \mathrm{dL}$ for high-fat diet group and normal group, respectively. The rats treated by high-fat chow were then randomly grouped into 6 groups including: Control group, simvastatin treated group, B100, M200, B50+M100, and $\mathrm{B} 100+\mathrm{M} 200$

The cholesterol serum level post-induction was shown in Table 2 . Furthermore, the percentage reduction in TC levels are calculated and statistically analyzed. There was an increase in TC levels at day 7 and 14. According to Table 2, a group of simvastatin $3.6 \mathrm{mg} / \mathrm{kg}$ bw, mulberry $200 \mathrm{mg} / \mathrm{kg}$ bw, both combination groups (B500+M100 and B100+M200) were statistically significant in reducing cholesterol serum levels within 14 days treatment $(\mathrm{p}<0.05)$. Even though TC level went down by $17.04 \%$ in a binahong treated group with a dose of $100 \mathrm{mg} / \mathrm{kg}$ bw, it was statistically similar to that of the control group. The highest reduction in this parameter was represented by group of B100+M200, in which the TC was suppressed by $44.81 \%$.

\section{TG serum level}

TG profile is presented in Table 3. According to Table 3, there was a significant reduction on TG levels by $23.09 \%$ compared to the control group (T7). On day 14 (T14), mulberry with a dose $200 \mathrm{mg} / \mathrm{kg}$, lower dose combination, and higher dose combination were able to lowering TG profile by $43.93 \%, 37.94 \%$, and $47.30 \%$, respectively. Meanwhile, at T21, M200, and B50+M100 group caused reduction on TG serum levels by $64.11 \%$ and $57.99 \%$, statistically remarkable compared to the control group. Nevertheless, there was amelioration in all treated groups at T14 and T21. Binahong and mulberry extract in both combination group had the lower TG levels than that of simvastatin $3.6 \mathrm{mg} / \mathrm{kg}$ bw. Rats treated by mulberry extract $200 \mathrm{mg} / \mathrm{kg}$ bw had better TG compared to the control group, in which was presented by the higher reduction (64.11\%) than that of simvastatin (33.39\%). Thus, we may conclude that administration of mulberry $200 \mathrm{mg} / \mathrm{kg}$ bw shows antihypertriglyceridemic effect.

\section{HDL serum levels}

The HDL serum levels are presented in Table 4. According to this Table 4, there was no significant difference between all groups with the control group. However, there was a slight increase in the level of HDL throughout the treatment period.

Table 1: The results of quality control of crude herbs and extracts

\begin{tabular}{|c|c|c|c|c|}
\hline \multirow[t]{2}{*}{ Parameters } & \multicolumn{2}{|c|}{ Binahong leaves } & \multicolumn{2}{|c|}{ Mulberry leaves } \\
\hline & $\begin{array}{l}\text { Crude } \\
\text { herb }\end{array}$ & Extract & $\begin{array}{l}\text { Crude } \\
\text { herb }\end{array}$ & Extract \\
\hline \multicolumn{5}{|l|}{ Secondary metabolite } \\
\hline Alkaloid & + & + & + & + \\
\hline Flavonoid & + & + & + & + \\
\hline Fenol & + & + & + & + \\
\hline Tanin & + & + & + & + \\
\hline Kuinon & - & - & - & - \\
\hline Steroid/Triterpenoid & + & + & + & + \\
\hline Saponin & + & + & + & + \\
\hline \multicolumn{5}{|l|}{ Determination of quality } \\
\hline Specific gravity (g/ml) & - & 1.48 & - & 0.97 \\
\hline Water content $(\% \mathrm{w} / \mathrm{v})$ & - & 30.00 & - & 20.00 \\
\hline $\begin{array}{l}\text { Extractable matter in water } \\
(\% \mathrm{w} / \mathrm{w})\end{array}$ & - & 8.46 & - & 5.88 \\
\hline $\begin{array}{l}\text { Extractable matter in } \\
\text { ethanol }(\% \mathrm{w} / \mathrm{w})\end{array}$ & - & 11.14 & - & 12.46 \\
\hline Total ash content (\%) & - & 26.43 & - & 4.16 \\
\hline Yield of extract (\%) & - & 24.20 & - & 13.17 \\
\hline
\end{tabular}

+: Detectable, -: Undetectable, in the determination of quality section (-) means it was not performed 
Table 2: The results of TC serum

\begin{tabular}{|c|c|c|c|c|}
\hline \multirow[t]{2}{*}{ Group } & \multicolumn{4}{|c|}{ TC serum level (mg/dL) } \\
\hline & T0 & T7 & T14 & T21 \\
\hline Normal & $52.33 \pm 10.44$ & $52.33 \pm 2.52(0.38 \pm 10.44)$ & $47.33 \pm 4.73(-9.70 \pm 4.38)$ & $41.00 \pm 2.65(-21.55 \pm 5.39)$ \\
\hline Simvastatin & $321.75 \pm 10.40^{\#}$ & $248.50 \pm 54.14(-21.28 \pm 10.40)^{*}$ & $194.75 \pm 41.76(-38.27 \pm 9.22)^{*}$ & $147.25 \pm 22.38(-52.86 \pm 7.23)^{*}$ \\
\hline B100 & $338.00 \pm 4.08^{\#}$ & $295.25 \pm 117.20(-11.82 \pm 4.08)$ & $280.00 \pm 119.50(-17.04 \pm 5.17)^{*}$ & $230.50 \pm 148.47(-37.32 \pm 17.66)^{*}$ \\
\hline M200 & $323.50 \pm 13.90^{\#}$ & $277.50 \pm 105.80(-15.40 \pm 13.90)$ & $219.25 \pm 90.16(-33.68 \pm 9.45)^{*}$ & $185.75 \pm 65.36(-42.87 \pm 8.12)^{*}$ \\
\hline $\mathrm{B} 50+\mathrm{M} 100$ & $337.25 \pm 20.92^{\#}$ & $249.00 \pm 101.76(-27.69 \pm 20.92)^{*}$ & $220.25 \pm 30.55(-34.39 \pm 3.02)^{*}$ & $151.75 \pm 10.53(-54.10 \pm 7.73)^{*}$ \\
\hline $\mathrm{B} 100+\mathrm{M} 200$ & $331.00 \pm 8.71^{\#}$ & $271.50 \pm 91.36(-18.74 \pm 8.71)$ & $182.75 \pm 54.11(-44.81 \pm 2.82)^{*}$ & $132.00 \pm 34.73(-59.61 \pm 8.24)^{*}$ \\
\hline
\end{tabular}

\#Expresses that there is a statistically significant difference from the normal group. *Expresses that there is a statistically different from the control group. Number on the first line refers to TC level (mg/dL), meanwhile numbers in the second line means percentage of reduction between selected time with T0 (\%). TC: Total cholesterol

Table 3: Results of TG measurement

\begin{tabular}{|c|c|c|c|c|}
\hline \multirow[t]{2}{*}{ Group } & \multicolumn{4}{|c|}{ TG serum level (mg/dL) } \\
\hline & T0 & T7 & T14 & T21 \\
\hline Normal & $138.33 \pm 51.03$ & $139.67 \pm 43.66(4.32 \pm 30.51)$ & $106.67 \pm 34.08(-21.53 \pm 9.82)$ & $80.67 \pm 43.88(-44.06 \pm 9.66)$ \\
\hline Simvastatin & $100.00 \pm 12.30$ & $95.75 \pm 20.02(-2.47 \pm 28.52)$ & $83.00 \pm 28.13(-16.36 \pm 27.85)$ & $63.25 \pm 28.95(-33.39 \pm 40.83)$ \\
\hline B100 & $147.00 \pm 49.17$ & $137.75 \pm 51.57(-5.37 \pm 21.09)$ & $112.50 \pm 72.48(-25.49 \pm 33.75)$ & $106.25 \pm 73.95(-31.43 \pm 34.11)$ \\
\hline M200 & $121.25 \pm 26.23$ & $124.75 \pm 55.54(5.60 \pm 49.58)$ & $66.50 \pm 18.65(-43.93 \pm 15.20)^{*}$ & $43.00 \pm 9.76(-64.11 \pm 6.76)^{*}$ \\
\hline B50+M100 & $145.00 \pm 53.23$ & $107.25 \pm 24.45(-23.09 \pm 15.46)^{*}$ & $82.00 \pm 11.80(-37.94 \pm 22.37)^{*}$ & $60.00 \pm 18.97(-57.99 \pm 5.99) *$ \\
\hline B100+M200 & $136.00 \pm 66.80$ & $120.00 \pm 35.67(-2.50 \pm 35.58)$ & $63.50 \pm 9.68(-47.30 \pm 17.93)^{*}$ & $69.50 \pm 37.55(-35.13 \pm 48.78)$ \\
\hline
\end{tabular}

*Means statistically different from the control group. Number on the first line refers to TC level (mg/dL), meanwhile numbers in the second line means percentage of reduction between selected time with T0 (\%). TG: Triglyceride

Table 4: Results of HDL measurement

\begin{tabular}{|c|c|c|c|c|}
\hline \multirow[t]{2}{*}{ Group } & \multicolumn{4}{|c|}{ HDL (mg/dL) } \\
\hline & T0 & T7 & T14 & T21 \\
\hline Normal & $12.00 \pm 2.00$ & $12.67 \pm 0.58(7.06 \pm 13.62)$ & $16.33 \pm 2.31(38.49 \pm 27.47)$ & $19.33 \pm 6.43(58.25 \pm 33.66)$ \\
\hline Control & $13.67 \pm 3.51$ & $14.00 \pm 2.00(10.20 \pm 45.57)$ & $18.33 \pm 3.51(41.79 \pm 47.77)$ & $19.33 \pm 5.69(40.39 \pm 10.02)$ \\
\hline Simvastatin & $8.75 \pm 3.69$ & $15.00 \pm 1.41(102.60 \pm 102.85)$ & $19.75 \pm 6.55(147.60 \pm 92.65)$ & $19.75 \pm 8.62(138.09 \pm 73.85)$ \\
\hline B100 & $9.50 \pm 3.11$ & $13.50 \pm 1.00(49.95 \pm 33.16)$ & $18.75 \pm 3.30(106.85 \pm 51.40)$ & $19.50 \pm 5.32(120.59 \pm 84.45)$ \\
\hline M200 & $8.25 \pm 2.63$ & $12.50 \pm 2.38(62.20 \pm 51.18$ & $17.25 \pm 2.22(117.56 \pm 35.68)$ & $24.50 \pm 2.65(212.50 \pm 72.17) *$ \\
\hline B100+M200 & $7.50 \pm 3.00$ & $14.75 \pm 2.87(124.19 \pm 102.92)$ & $20.25 \pm 4.65(213.89 \pm 163.39)^{*}$ & $18.75 \pm 4.79(172.07 \pm 104.97)$ \\
\hline
\end{tabular}

*Means statistically different from the control group. Number on the first line refers to TC level (mg/dL), meanwhile numbers in the second line means percentage of reduction between selected time with T0 (\%). TC: Total cholesterol, HDL: High-density lipoprotein

Table 5: Estimation of LDL after calculating by Friedewald Formula

\begin{tabular}{lllll}
\hline \multirow{2}{*}{ Group } & LDL $(\mathbf{m g} / \mathbf{d L})$ & & & T21 \\
\cline { 2 - 5 } & T0 & T7 & T14 & $5.53 \pm 2.53(-39.45 \pm 51.59)$ \\
Normal & $12.67 \pm 9.15^{\#}$ & $11.73 \pm 6.31(9.95 \pm 53.92)$ & $9.67 \pm 3.01(-5.23 \pm 39.99)$ & $296.60 \pm 186.79(-4.18 \pm 36.97)$ \\
Control & $304.40 \pm 105.11$ & $320.07 \pm 158.20(0.92 \pm 28.91)$ & $325.07 \pm 171.18(1.65 \pm 22.33)$ & $114.85 \pm 29.40(-59.76 \pm 8.41)^{*}$ \\
Simvastatin & $282.75 \pm 108.28$ & $214.35 \pm 54.70(-20.93 \pm 15.05)$ & $158.40 \pm 50.85(-42.96 \pm 10.11)^{*}$ & $189.75 \pm 136.11(-43.16 \pm 19.78)^{*}$ \\
B100 & $299.10 \pm 136.40$ & $254.20 \pm 111.56(-14.47 \pm 3.11)$ & $238.75 \pm 109.92(-19.53 \pm 8.52)$ & $152.65 \pm 62.20(-48.08 \pm 9.67)^{*}$ \\
M200 & $291.00 \pm 91.95$ & $240.05 \pm 104.91(-19.03 \pm 19.31)$ & $188.70 \pm 85.03(-36.86 \pm 10.88)^{*}$ & $115.00 \pm 14.42(-60.72 \pm 8.18)^{*}$ \\
B50+M100 & $298.25 \pm 48.60$ & $212.80 \pm 99.72(-30.67 \pm 24.45)$ & $187.60 \pm 32.30(-37.16 \pm 0.78)^{*}$ & $99.35 \pm 37.86(-67.00 \pm 8.96)^{*}$ \\
B100+M200 & $296.30 \pm 79.98$ & $232.75 \pm 88.25(-23.02 \pm 13.07)$ & $149.80 \pm 51.66(-49.99 \pm 5.37)^{*}$ & \\
\hline "There is a statistically significant difference compared to the normal group (p<0.05). *Means statistically different from the control group (p<0.05). Number on the \\
first line refers to TC level (mg/dL), meanwhile numbers in the second line means percentage of reduction between selected time with T0 (\%). TC: Total cholesterol, \\
LDL: Low-density lipoprotein
\end{tabular}

\section{LDL serum levels}

The levels of LDL cholesterol were calculated by Friedewald's equation, which results are shown in Table 5.

After induction, rats fed with high-fat diet showed a significant elevation in the LDL concentration compared with the normal group. That of control group remained relatively stable throughout the period. On the contrary, the groups treated by simvastatin $3.6 \mathrm{mg} / \mathrm{kg}$ bw, mulberry extract $200 \mathrm{mg} / \mathrm{kg}$ bw, and both combination groups showed a significant reduction in LDL serum levels. Combination of binahong and mulberry extract in lower and higher dose showed that reduction in LDL cholesterol occurred in a dose-dependent manner.

\section{Liver index}

As given in Table 6, the value of liver index was not significantly different in all groups compared to the control group. However, the liver index was found to be remarkably higher in the high-fat diet rat comparing to the normal group, despite they were treated by tested substances. 
Macroscopic and microscopic observation

Macroscopic and microscopic observation of liver is depicted in Figs. 1 and 2, respectively. Even though in general there were ameliorations on lipid profile in treated groups, macroscopically, the appearance of treated rat's liver was similar to that of the control group. Comparing to the normal liver, high fat-fed rat, both with treatment or not, became very pale and there was an increase in size, along with the spread of white spot all over the organ. We assumed that administration of highfat diet caused accumulation, especially in the liver leading to such appearances. According to these results, administration of simvastatin and extracts were not able to improve liver macroscopically.

Furthermore, liver that was already observed quickly, then it was prepared for histopathological studies. Fig. 2 shows a liver microscopically with 100 times optical magnification.

\section{DISCUSSIONS}

This study is the initial study to demonstrate beneficial effects from administration of binahong leaves and mulberry leaves extracts in combination in a high-fat diet-induced hyperlipidemia rats. The main results show that combination of both extracts is able to lowering mainly the TC level, LDL, and triglyceride. In addition, there is a slight increase in the level of HDL throughout the period. The model of dyslipidemia was obtained by feeding experimental rats for a certain period, in this case was 30 days, by high-fat chow. This model is a common model to evaluate the pharmacological effect of certain substances on dyslipidemia. As rats were in high-fat diet, they gained more adipose tissue and sometimes acquired the insulin resistance and hyperleptinemia which are typically associated with obesity [9].

Hyperlipidemia is reported having major risk factor for coronary heart disease through several ways, such as decreasing myocardial nitric oxide concentration, exacerbate radical oxygen, activating apoptotic caspase-3, leading to cholesterol accumulation in the mitochondrial membrane and sarcolemma [10,11]. Hyperlipidemia is highly associated with cardiovascular diseases. Reducing the level of "bad cholesterol" such as TC, LDL, and TG to the normal acceptable range is beneficial to lowering morbidity and mortality in cardiovascular diseases [12]. High-fat diet for 30 days in our recent study significantly increased serum concentration of TC, TG, and LDL.

The extract of binahong has a broad range of pharmacological activities such as repairing renal damage [13], reducing endothelial fat [4] and acts as antihyperuricemic agents [14], antimicrobial agent [15], antifungi [16], antihypertension [17], anti-inflammation [18-20], antiobesity [21], etc. Essential oil extracted from Anredera cordifolia possessed weak inhibitory activity against the Gram-positive pathogens [22]. Sukandar et al. reported ethanolic extract of binahong leaves was considerably safe to be used in pregnancy [23] and in a long term preclinically [24]. Indeed, consumption of extract for long term does not harm and considerably safe to be used in treating dyslipidemia.

Zinchen et al. reported that his team successfully evaluated the antioxidant content from different parts of mulberry trees [25]. The branches of mulberry trees have the highest scavenging abilities from its flavonoid. Meanwhile, leaves and tender leaves contained approximately $46.5 \%$ and $67.5 \%$ flavonoid, respectively [26]. Mulberry fruit extract also reported inhibited development of atheroma plaque in cholesterol-fed rabbits [27]. Mulberry is also known as traditional edible fruit that is able to treat fever, protect liver, strengthen the joints, and improve blood pressure [26]. However, the biological and pharmacological of mulberry fruit are still poorly understood [27].

In accordance to the literature study and the results of our study, combination of binahong leaves extracts and mulberry leaves extracts showed a synergistic effect in ameliorating lipid profile in a dosedependent manner. We assumed that as the higher dose is used, the active compounds become larger resulting in better efficacy on hyperlipidemia rat model. However, in revealing the mechanism of
Table 6: Liver index at the end point of experiment

\begin{tabular}{ll}
\hline Group & Liver index (\%) \\
\hline Normal & $3.20 \pm 0.19^{*}$ \\
Control & $5.01 \pm 0.12^{\#}$ \\
Simvastatin & $4.92 \pm 0.61^{\#}$ \\
B100 & $5.18 \pm 0.35^{\#}$ \\
M200 & $4.76 \pm 0.48^{\#}$ \\
B50+M100 & $4.81 \pm 0.48^{\#}$ \\
\hline
\end{tabular}

${ }^{*} \mathrm{p}<0.05$ compared to the control group. ${ }^{*} \mathrm{p}<0.05$ compared to the normal group

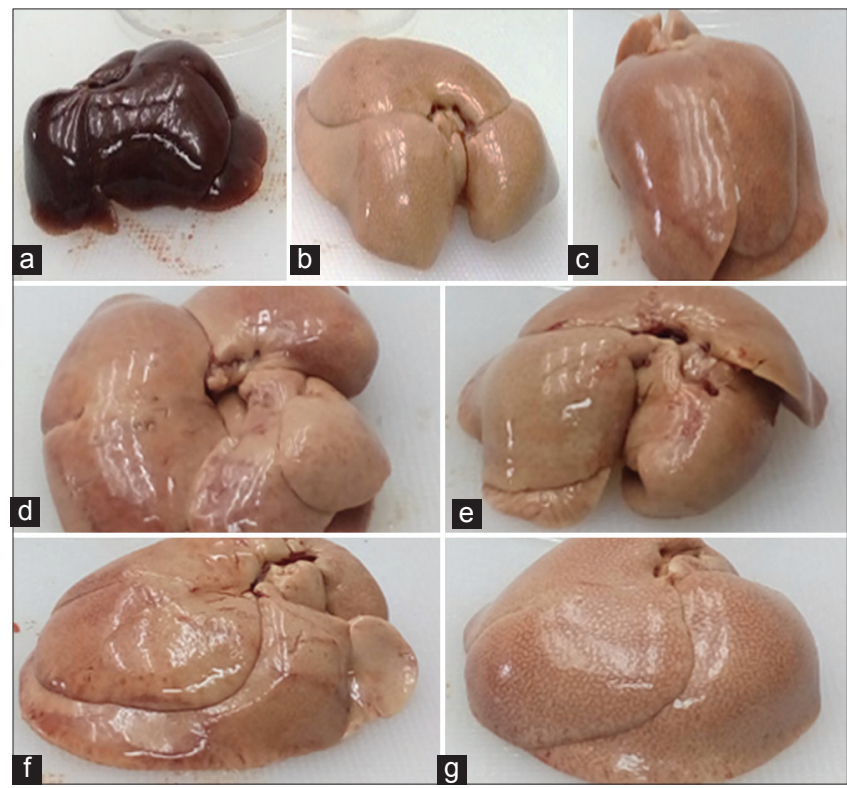

Fig 1: Macroscopic appearance of liver as representatives from groups (a) normal (b) control (c) simvastatin $3.6 \mathrm{mg} / \mathrm{kg}$ bw (d) B100 (e) M200 (f) B50+M100 and (g) B100+M200

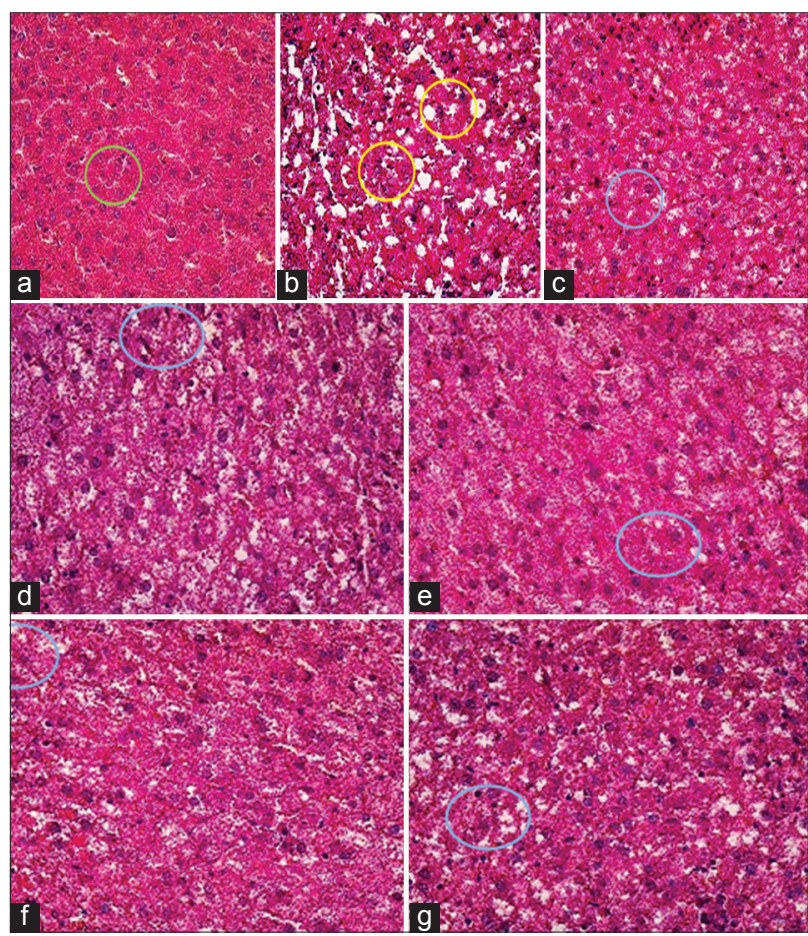

Fig 2: Histologic appearance of representative liver from a group of: (a) normal, (b) control, (c) simvastatin, (d) B100, (e) M200,

(f) $\mathrm{B} 50+\mathrm{M100}$, (g) B100+M200. Green circle shows a normal density of hepatocytes. Meanwhile other circles points to empty vesicles which are not commonly found in the normal liver 
action of each extract, there should be a further study to reveal the mechanism of action and isolation of corresponding compounds that attribute to this pharmacological effect.

\section{CONCLUSION}

Administration of mulberry extract with a dose of $200 \mathrm{mg} / \mathrm{kg}$ and binahong leaves extract, both as single administration and in combination for 21 days were able to ameliorate lipid profile in hypercholesterolemia-induced rats. Extracts in combination showed higher potency in the dose-dependent manner in reducing TC and LDL serum levels significantly compared to control as well as simvastatin as a reference drug

\section{REFERENCES}

1. Dipiro JT, Talbert RL, Yee GC, Matzke GR, Wells BG, Posey LM Pharmacotherapy a Patophysiologic Approach. $8^{\text {th }}$ ed. Columbia: McGraw Hill; 2011. p. 1267-79.

2. National Cholesterol Education Program (NCEP). ATP III Guidelines At-A-Glance Quick Desk Reference. United Stateds: National Institute of Health; 2011. p. 01-3305.

3. American Heart Association (AHA) Statistics Committee and Stroke Statistics Subcommittee. Heart Disease and Stroke Statistics-2013 Update: A Report from the American Heart Association. United States: American Heart Association. Circulation 2013;127:6-245. Available from: https://www.heart.org/idc/groups/heart-public/@wcm/@sop/@ smd/documents/downloadable/ucm 319586.pdf.

4. Lestari D, Sukandar EY, Fidrianny I. Anredera cordifolia leaves extract as antihyperlipidemia and endothelial fat content reducer in male wista rat. Int J Pharm Clin Res 2015;7(6):435-9.

5. Hou Y, Shao W, Xiao R, Xu K, Ma Z, Johnstone BH, et al. Pu-erh tea aqueous extracts lower atherosclerotic risk factors in a rat hyperlipidemia model. Exp Gerontol 2009;44(6-7):434-9.

6. Lestari D. Combination of rumput teki rhizome (Cyperus rotunda L.) and Mulberry leaves (Morus alba L.) towards cholesterol and its effect on inhibiting atheroma plaque on male wistar rats. Theses Book of Master Degree. Bandung: Institut Teknologi Bandung; 2012.

7. Rahman AA. Preventive effect of binahong leaves extract (Anredera cordifolia (Ten.) Steenis) on lipid profile in high-fat induced Wistar rats. Theses of Master Degree. Bandung: Institut Teknologi Bandung; 2015.

8. World Health Organization (WHO). Cardivascular Diseases Fact Sheets. World Health Organization (WHO); 2012. Available from: http://www.who.int/mediacentre/factsheets/fs317/en/.

9. Woods SC, Seeley RJ, Rushing PA, D’Alessio D, Tso P. A controlled highfat diet induces an obese syndrome in rats. J Nutr 2003;133(4):1081-7.

10. Balakumar P, Babbar L. Preconditioning the hyperlipidemic myocardium: Fact or fantasy? Cell Signal 2012;24(3):589-95.

11. Yadav HN, Singh M, Sharma PL. Modulation of the cardioprotective effect of ischemic preconditioning in hyperlipidaemic rat heart. Eur J Pharmacol 2010;643(1):78-83.

12. Munshi RP, Joshi SG, Rane BN. Development of an experimental die model in rats to study hyperlipidemia and insulin resistance, markers for coronary heart disease. Indian J Pharmacol 2014;46(3):270-6.
13. Sukandar EY, Sigit JI, Adiwibowo LF. Study of kidney repair mechanisms of corn silk (Zea mays L. Hair)-binahong. Int J Pharmacol 2013;9(1):12-23

14. Widyarini KD, Sukandar EY, Fidrianny I. Xanthine oxidase inhibitory and antihyperuricemic activities of Anredera cordifolia (Ten) steenis, Sonchus arvensis $\mathrm{L}$, and its combination. Int J Pharm Pharm Sci 2015;7(3):86-90.

15. Garmana AN, Sukandar EY, Fidrianny I. Activity of several plant extracts against drug-sensitive and drug-resistant microbes. Procedia Chem 2014;13:164-9.

16. Indriyanti N, Adnyana IK, Sukandar EY. The study of antifungal effect of binahong (Anredera cordifolia) dan the root of Petiveria alliacea The Final Project Book of Undergraduate Students. Bandung: Institut Teknologi Bandung; 2011.

17. Garmana AN, Sukandar EY, Fidrianny I. Preliminary study of blood pressure lowering effect of Anredera cordifolia (Ten.) Steenis) on wistar rats. Int J Pharmacogn Phytochem Res 2016;8(2):300-4.

18. Salasanti CD, Sukandar EY, Fidrianny I. Acute and sub chronic toxicity study of ethanol extract of Anredera cordifolia (Ten.) v. Steenis leaves. Int J Pharm Pharm Sci 2014;6(5):348-52.

19. Urmila GH, Satyanarayana T, Rao BG. Antihyperlipidemic activity of methanolic leaf extract of three different plants on high cholesterol diet induced hyperlipidemic rats. Int J Preclin Pharm Res 2014;5(1):30-3.

20. Juwita R, Sukandar EY, Fidrianny I, Hasimun P. Uji Efek Antihiperlipidemia Ekstrak Etanol Daun Binahong (Anredera cordifolia) Terhadap Tikus Wistar Jantan Dengan Metode Homeostatis Kolesterol. The Final Project Book of Undergraduate Students. Bandung: Institut Teknologi Bandung; 2011.

21. Sukandar EY, Kurniati NF, Nurdianti AN. Antiobesity effect of ethano extract of Anredera cordifolia (Ten.) Steenis leaves on obese male wistar rats induced by high_carbohydrate diet. Int J Pharm Pharm Sci 2016;8(4):171-3.

22. Souza LF, de barros IB, Mancini E, De martino L,Scandolera E, De Feo V. Chemical composition and biological activities of the essential oil from Anredera cordifolia grown in Brazil. Nat Prod Commun 2014;9(7):1003-6.

23. Sukandar EY, Kurniati NF. Evaluation of teratogenicity effects of ethanolic extracts of binahong leaves (Anredera Cordifolia (Ten) steenis) in wistar rat. Int J Pharm Pharm Sci 2014;6(11):422-6.

24. Sukandar EY, Fidrianny I, Nofianti T, Safitri D. Subchronic toxicity study of corn silk (Zea mays L.) In combination with binahong (Anredera cordifolia (Ten.) Steenis leaves on wistar rats. Asian J Pharm Clin Res 2016;9(1), 292-6.

25. Zhishen J, Mengcheng T, Jianming W. The determination of flavonoid contents in mulberry and their scavenging effects on superoxide radicals. Food Chem 1999;64(4):555-9.

26. Chen CC, Liu LK, Hsu JD, Huang HP, Yang MY, Wang CJ. Mulberry extract inhibits the development of atherosclerosis in cholesterol-fed rabbits. Food Chem 2005;91(4):601-7.

27. Gerasopoulos D, Stavorulakis G. Quality characteristics of four mulberry (Morus sp.) Cultivars in the area of China, Greece. J Sci Food Agric 1997;73:261-4 